УДК 34

DOI https://doi.org/10.51989/NUL.2021.4.8

\title{
БІОСОЦІАЛЬНИЙ ВИМІР ЛЮДСЬКОГО БУТТЯ ЯК ОСНОВНА ХАРАКТЕРИСТИКА ПРАВА НА ЖИТТЯ
}

\author{
Романів Христина Богданівна, \\ кандидат юридичних наук, \\ доцент кафедри цивільно-правових дисциплін \\ Львівського державного університету внутрішніх справ
}

Актуальність статті полягає в новому погляді на поняття «право на життя» через філософсько-правовий підхід, який передбачає визнання життя та невід'ємні від нього здоров'я, честь та гідність найвищими соціальними цінностями. Це означає, що надання переваг іншим цінностям не допускається. Внаслідок аналізу значного наукового матеріалу вдалося встановити такі ознаки права на житт: воно є невід'ємним, невідчужуваним і непорушним, а отже, природнім правом; право на життя характеризується рівністю (загальністю) та універсальністю; $\epsilon$ фундаментальним та абсолютним правом; немайновий, особистісний характер права на життя, неможливість поновлення та неможливість правонаступництва; передбачає тісний зв'язок з людиною як носієм цього права; об'єктом правової охорони права на життя є життя як єдність буття у трьох його формах: фізіологічній, соціологічній та внутрішній (духовній).

Розкриття основних ознак права на життя допомогло нам установити, що людину як носія цього права необхідно розглядати як біосоціальну істоту, яка володіє здатністю жити не лише як біологічний вид, але і як соціальний. Відповідно, людина включає поняття «особистість» й «індивід», де поняттю особистості відповідають соціальна і духовна сторони людського буття, а поняттю «індивід» - біологічна, природна сторона. Враховуючи це, характеристика людини має виходити з їі біологічних ознак з акцентом на соціальну, культурну, духовно-моральну сторону. Людина - це біосоціальна істота, яка володіє такими тільки їй притаманними ознаками, як: свідомість, свобода, творчість, мислення, мова тощо та поєднує в собі фізичний, соціальний, духовний та моральний аспекти. Тому об'єктом правової охорони права на життя є життя як єдність трьох форм бутт: фізіологічного, соціологічного та духовного.

Ключові слова: право на життя, гідність, людина, філософія права.

\section{Romaniv Khrystyna. Biosocial dimension of human existence as the main characteristic of the right to life}

The relevance of this article is in its new insight into "right to life" through a philosophical and legal approach, which provides the recognition of life and its integral elements such as health, honour and dignity as the highest social values. It means that giving preference to other values is unacceptable. As a result of the analysis of sufficient scientific material, it was possible to establish the following features of the right and life, in particular: it is integral, inalienable and inviolable, so it is a natural right; the right to life is characterized by its equality (generality) and universality; it is a fundamental and absolute right; nonmaterial and personal nature of the right to life, impossibility of renewal or impossibility of succession; it provides a close connection with a person - the holder of this right; the object of legal protection of the right to life is life as the unity of existence in its three forms: physiological, sociological and internal (spiritual).

The discovery of the basic features of the right to life has helped us to fix that a person as the holder of this right should be considered as a biosocial being who has an ability to live not only as a biological species but as a social one as well. Accordingly, person includes the concepts of "personality" and "individual", where social and spiritual aspects of human existence correspond to the concept of "personality", and biological and natural aspects correspond to the concept of "individual". Taking this into account, the characteristics of a person should be based on his biological features with an accent on social, cultural, spiritual and moral side. A person is a biosocial being who has only his inherent features: consciousness, freedom, creativity, thinking, speech, etc. and combines physical, social, spiritual and moral aspects in him. Hence, the object of legal protection of the right to life is the life as the unity of existence in its three forms: physiological, sociological and spiritual.

Key words: right to life, dignity, person, philosophy of law. 
Право на життя $\epsilon$ основним, фундаментальним правом людини, без якого всі інші права $\epsilon$ беззмістовними. У визнанні права людини на життя, згідно з Конституцією України, ключовим є положення ч. 1 ст. 27, де вказано, що це право $€$ невід'ємним, та ст. 21, яка наголошує, що воно $€$ невідчужуваним і непорушним [1]. На основі Конституції та власних міркувань щодо ознак права на життя людини вважаємо, що дане право характеризується такими особливостями:

- $\epsilon$ невід'ємним, невідчужуваним і непорушним, а отже, природнім правом;

- право на життя характеризується рівністю (загальністю) та універсальністю;

- $\epsilon$ фундаментальним та абсолютним правом;

- немайновий, особистісний характер права на життя, неможливість поновлення та неможливість правонаступництва;

- передбачає тісний зв'язок з людиною як носієм цього права;

- об'єктом правової охорони права на життя $\epsilon$ життя як єдність буття у трьох його формах: фізіологічного, соціологічного та внутрішнього (духовного).

Спробуємо охарактеризувати наведені особливості права на життя.

Першою ознакою $\epsilon$ те, що право на життя $\epsilon$ природнім, а отже, невід'ємним, невідчужуваним та непорушним.

Під невід'ємністю права на життя розуміється неможливість позбавити людину таких прав, а під невідчужуваністю - у неможливості їх передачі. Не можна передати, продати, подарувати своє життя, здоров'я, гідність, адже якщо не існує їх, немає і самої людини. У характеристиці невідчужуваності актуальні, ще як ніколи, слова Г.Ф. Гегеля, який виділив два моменти: 1) ці права ніхто не дарує людині, і їх не можна в неї відібрати, не зруйнувавши саму людську особистість; 2) людина не може передати дані права, навіть якщо в неї виникне таке бажання [2, с. 38-39]. Згідно з природно-правовою концепцією права людини $\epsilon$ невід'ємними, природженими або дарованими Богом. Це абсолютні й деякою мірою позаісторичні цінності, позбавляти яких чи обмежувати які ніхто не має права. Як стверджують прихильники природно-правової концеп- ції, людина наділяється невід'ємними правами з народження [3, с. 26-27]. Природними називають такі права людини, які $\epsilon$ властивостями людини як живої істоти. Безперечним $\epsilon$ факт, що основною такою властивістю вважається життя людини, а тому найважливішим із природних прав буде право на життя. Всі інші права об'єднуються навколо цього стрижневого основного права [4, с. 43]. Право на життя $\epsilon$ невід'ємним тому, що становить собою якості, «які іманентні людині як життєдіяльній істоті та які не можна відділити від неї без явної загрози втратити в ній члена суспільного союзу» [5, с. 30].

3 точки зору теорії природного права природні права можна вважати похідними від природного стану речей, тобто в незалежності від волі людини її організм розвивається за певними біологічними законами, оскільки вона $\epsilon$ невіддільною частиною світового порядку. У процесі життєдіяльності людина примушена безперервно здійснювати вибір варіантів своєї поведінки, оскільки це зумовлено особливістю її біологічної організації, а також необхідною умовою розвитку. У свою чергу позитивне закріплення прав людини - штучне утворення, створене людьми, віддане інтересам такого штучного формоутворення, як держава. Через принципи природного права індивідуальна правосвідомість людини пов'язує своє існування з універсальною першоосновою буття [6, с. 95-96]. Право на життя як природне право носить безпосередній (прямий) і об'єктивний характер реалізації. Безпосередній характер реалізації означає те, що воно реалізується без якого 6 то не було правозастосовувального акту. Також реалізація природних прав здійснюється незалежно від волі людей, тобто об'єктивно. Людина не вибирає батьків, статі, часу й місця народження - це все вона, подорослішавши, сприймає як об'єктивну даність [7, с. 14]. Отже, природно те, чого не можна заборонити, відмінити, що не залежить від бажання і волі людини, що відбувається по «графіку», створеному природою. Розгляд природніх прав людини в такому аспекті можливий тільки через призму біологічних характеристик людського організму (наприклад, право на сон, на отримання їжі й води) [8, c. 286-287]. 
Дане право не залежить від визнання або невизнання його державою, не може бути обмежено або скасовано будьякими органами влади, тому що існує як об'єктивна реальність, зумовлена людською сутністю і природою людини. Тому в загальних рисах право на життя можна визначити як право, властиве природі людини, без якого вона не може існувати як людська істота. Це право засноване на постійному зростанні вимог людства в такому житті, яке би відповідало сьогоденним соціально-економічним і духовним потребам, за яких завжди залишаються невід'ємними гідність і цінність кожної людської особистості.

Таким чином, в основі природного права лежать історичні цінності та культурні надбання, моральні ідеали, тому воно $€$ ідеальною побудовою, продуктом культури, а отже, має об'єктивну природу. Право на життя $€$ об'єктивним правом і це випливає з таких положень:

- по-перше, природні права не підвладні юридичним законам, адже від норми, закріпленої в законі, не залежить, чи народиться людина чи ні, як і від самої людини не залежить вибір батьків, статті, зовнішності тощо. Позитивне право $\epsilon$ інституалізацією природних прав, а не навпаки;

- по-друге, життя людини, його виникнення, здійснення і припинення відбувається за законами природи.

Природність права на життя випливає виключно з властивостей самої особистості. Право людини на життя існує не в залежності від його нормативного закріплення, адже саме життя виникло перше, ніж право, а мета існування права - це врегулювання суспільних відносин. Мета закріплення прав - це зафіксувати обов'язок держави щодо захисту цього права у разі його порушення і надання реальних можливостей його реалізації. Також таке нормативне закріплення сприяє постійному розвитку прав, які залежать від розвитку правової системи в державі та всього правового суспільства загалом. Отже, нормативне закріплення гарантує можливість реалізації людиною таких прав. Поряд із тим цінність, яку воно захищає, $\epsilon$ реальністю і належить людині незалежно від нормативного закріплення. Отже, природ- ність права на життя - це не «мода» на демократичність чи красива нормативна декларація як потреба правового суспільства, це ідея, зумовлена розвитком людства та реальною потребою людського життя, ідея, що, як і все живе, розвивається, вдосконалюється і тому дотепер не втрачає своєї актуальності.

\section{Другою ознакою $\boldsymbol{\epsilon}$ фундаменталь-}

ність та абсолютність. Окрім того, що право на життя $\epsilon$ природнім, воно також $\epsilon$ і фундаментальним. Слово «фундаментальність» означає, що дане право $€$ головним, основоположним по відношенню до інших. Тобто без права на життя всі інші права позбавляються свого значення та перетворюються на порожню абстракцію. Право на життя в демократичному суспільстві виступає точкою відліку, критерієм усього інституту прав і свобод.

Те, що право на життя $\epsilon$ фундаментальним, указує на це закріплення його в Конституції України як Основному Законі держави. Окрім того, право на життя є ядром правового статусу особистості. Зокрема, Європейський Парламент схвалив Хартію фундаментальних прав Європейського Союзу (наприклад, Хартія визначає такі фундаментальні прав людини, як: право на життя (включаючи заборону смертної кари), право цілісності особи (включаючи заборону на селекцію людей та клонування) [9, с. 77].

Право на життя $\epsilon$ основоположним. Право на життя $\epsilon$ першоосновою або, за формулюванням Європейської Конвенції з прав людини, «загальною умовою існування» всіх інших прав і свобод людини. Можна характеризувати це право як абсолютну цінність світової цивілізації, найперше право людини, оскільки всі інші права в разі смерті людини втрачають сенс і значення [10, с. 115].

Право на життя людини $\epsilon$ також абсолютним правом, оскільки в таких відносинах уповноваженій особі протистоїть необмежене коло зобов'язаних осіб, які повинні утримуватися від вчинення дій, що можуть порушити особисте немайнове право іншої особи. У рамках закону володілець особистого права самостійно визначає, яким чином, коли і які зі своїх особистих прав здійснити. Людині надано право вільно визначати свою поведінку 
в індивідуальній сфері життєдіяльності [11, с. 35-36]. Під абсолютністю права на життя необхідно розуміти, що це право захищається проти всякого і кожного, від неправомірних посягань на нього; воно не може бути зупинено ніякими юридичними діями; суб'єкти можуть користуватися цим правом без спеціального дозволу, а межі користування встановлюються лише законом. Абсолютні права одного суб'єкта породжують абсолютні обов'язки в інших суб'єктів [9, с. 72]. Отже, абсолютність права на життя означає, що людина може самостійно вибирати характер своєї життєдіяльності та повну заборону на позбавлення життя будь-якої людини.

Ще однією ознакою права на життя $\epsilon$ рівність (загальність) та універсальність.

На загальнодержавному рівні вперше було визнано рівність природних прав у Декларації незалежності Сполучених Штатів Америки 1776 р.: «Ми вважаємо очевидними такі істини: всі люди створені рівними й всі вони обдаровані своїм творцем деякими невідчужуваними правами, до числа яких належать: життя, свобода і прагнення до щастя» [12]. Рівність у праві на життя полягає в тому, що кожна людина в незалежності від своїх фізичних чи духовних відмінностей від інших людей, від свого соціального статусу, релігійних уподобань, національності тощо має безумовну духовну гідність. У цій своїй людській гідності кожна людина рівна іншій. Таким чином, держава у своїй діяльності має враховувати фактичну нерівність людей, але виходити завжди з гідності людини.

Правом на життя володіють усі люди без якої-небудь дискримінації. Також загальність виражається в просторовому й територіальному аспекті. Зокрема, де 6 не перебувала людина, куди 6 вона не переміщувалась, вона володіє правом на життя. Право на життя - це не внутрішня справа держави, тому що ії захист - це справа всього міжнародного товариства. Право на життя - це так зване право без кордонів, тому єдине, що в змозі зробити держава, - це гарантувати надійний захист цього права, що може бути досягнуто через віднесення злочинів проти особи до особливо тяжких кримінально-караних діянь, а також встановлення покарання за їх вчинення [9, с. 75-76].

Отже, право на життя - це загальне право всіх людей, що підтверджує рівність між людьми незалежно від їхньої національності, віросповідання, історичних, культурних і релігійних особливостей, а також від того, де вони проживають, який суспільний лад, міжнародний статус, політичний режим, форма державного устрою і форма правління тощо $€$ в їхніх країнах.

Наступна ознака - немайновий, особистісний характер права на життя, неможливість поновлення та неможливість правонаступництва.

Право на життя $€$ особистісним, і це означає, що хоч і всі люди однакові й рівні в наданні цього права та його реалізації, однак у кожної людини їі життя - це її індивідуальність, її духовний світ, який невіддільний від неї. Існування права на життя неможливе поза зв'язком з певною особою, а тому право на життя неможливо здійснити іншою особою, навіть правонаступнику.

Право на життя виникає з приводу самого життя, яке має нематеріальний характер. Якщо матеріальні блага - засоби виробництва, речі, майно - $є$ цілком об'єктивно вимірні в тих чи інших одиницях, можуть бути виражені в доступній і рівнозначній для всіх формі та мають конкретні вимірювані параметри (як для власника цих прав, так і для інших осіб), то право на життя позбавлене цих якостей. Право на життя має цілком певний зміст, проте не піддається точному виміру, тобто вони не можуть бути зважені, визначені в грошових або будь-яких інших одиницях. Немайновість права на життя полягає в тому, що дане право позбавлене економічного змісту, тобто не може бути оцінене точно в будь-якому матеріальному еквіваленті. Також для даного права $\epsilon$ характерним те, що шкода, заподіяна його порушенням, на яку мають право родичі та інша категорія людей, передбачених законом, не піддається точній грошовій оцінці [11, с. 35].

Особистісний характер права на життя перетікає в ще одну індивідуальну ознаку права - неможливість їх повного відновлення в разі порушення. Щодо правонаступництва, то само собою зрозуміло, що 
це право як не може бути відчуженим, так само не може переходити в спадщину (як наприклад, право власності). Людина володіє цим правом до смерті.

Четвертою ознакою $\epsilon$ те, що право на життя тісно пов'язане 3 людиною носієм цього права.

Зрозуміло, що для права на життя вагоме значення має розуміння поняття «людина». Найперше, слід говорити про людину як біологічну істоту, адже з погляду біології людина за будовою тіла, функціонуванням організму, способом живлення тощо належить до тваринного світу. Проте людина у своїй сутності виходить далеко за межі біологічного [13, с. 12]. Позитивне право визнає, що людина через свою біологічну природу перебуває за все своє життя в різних станах, які характеризується неоднаковим рівнем правосвідомості, розуміння закону, вмінням аналізувати свою поведінку. Так, законодавець визнає, що як біологічна істота людина має початок і кінець, тому регламентує порядок реєстрації моменту народження і смерті, встановлює різні правоздатності, які залежать як від віку, так і від здоров'я тощо. Окрім того, законодавець бере до уваги і психічні можливості людини, які полягають у можливості аналізувати свої дії, тому встановив такі правові категорії, як «стан сильного душевного хвилювання», «стан афекту» тощо. До того ж людина постійно розвивається, і це підтверджують норми, якими встановлено вік, з якого людина може нести кримінальну, цивільну відповідальність, а також випадки, коли несуть відповідальність батьки, опікуни, піклувальники.

Натомість філософський підхід розглядає людину як суспільну істоту, яка являє собою найвищий ступінь розвитку живих організмів на Землі, суб'єкт суспільно-історичної діяльності та культури [14, с. 736]. 3 точки зору як повсякденного, так і наукового мислення, на думку А.М. Шульги, поняття «людина» $\epsilon$ неоднозначним, оскільки характеризується двоїстістю. 3 одного боку, за допомогою цього поняття ми мислимо про людину як родову істоту, а з іншого - як про будьякого конкретного індивіда. Однак це роздвоєння $€$ відносним, обидва його значення тісно пов'язані між собою, тому що людина як родова істота не може існувати незалежно від індивідів, від конкретних людей, з іншого боку, будь-який індивід $\epsilon$ більш-менш повним втіленням людського роду, наближенням до якоїсь ідеальної людини [15, с. 5-6]. На думку П. Рабіновича, поняття «людина», вказує на те, що людське в людині зосереджене головно в освоєних нею формах і способах життєдіяльності, що завжди реалізуються в певному соціально-культурному контексті [16, с. 168]. Тому якщо зосередити увагу на власне людині як носії права на життя, то сучасна наука репрезентує різні концепції людини, різні погляди на ії̈ природу. Найбільш наближеною до істини є концепція єдності «тілесно-соціальної організації» людини [15, с. 5-6], яку необхідно бачити в їі «біосоціальному» чи «соціобіологічному» зв'язку. Біологічне в людині це їі фізичний субстрат (тіло) і шар психіки, а соціальне в людині - це ансамбль їі особистісних властивостей [17, с. 69-70]. Діалектичний підхід до проблем біологічного та соціального в людині натепер розроблений недостатньо. Це виражається як у розумінні біологічного як «чисто природного», так і соціального як «позабіологічного». Однак біологічна організація міститься в соціальній, інтегрована нею, а соціальна зумовлюється можливостями біологічного, тому зрозуміло, що природне і соціальне органічно взаємопов'язані [18, с. 7-8].

На нашу думку, поняття «людина» включає поняття «особистості» й «індивіда», де поняттю «особистості» відповідають соціальна і духовна сторони людського буття, а поняттю «індивід» - біологічна, природна сторона. Так, під терміном «індивід» розуміють живу істоту, яка перебуває в єдності з навколишнім середовищем [19, с. 67]. У свою чергу особистість - це людина як соціальна істота, оскільки в ній виражається належність людини до певного суспільства, певної історичної епохи, культури, науки тощо [20, с. 18].

Висновки. Право на життя - це загальне право всіх людей, що підтверджує рівність між людьми незалежно від їхньої національності, віросповідання, історичних, культурних і релігійних особливостей, а також від того, де вони проживають, який суспільний лад, міжнародний статус, полі- 
тичний режим, форма державного устрою і форма правління тощо $€$ в їхніх країнах. У даній статті було встановлено такі ознаки права на життя: $\epsilon$ невід'ємним, невідчужуваним та непорушним, а отже, природнім правом; право на життя характеризується рівністю (загальністю) та універсальністю; $\epsilon$ фундаментальним та абсолютним правом; немайновий, особистісний характер права на життя, неможливість поновлення та неможливість правонаступництва; передбачає тісний зв'язок з людиною як носієм цього права; об'єктом правової охорони права на життя є життя як єдність буття у трьох його формах: фізіологічного, соціологічного та внутрішнього (духовного).

Розкриття основних ознак права на життя допомогло нам установити, що людину як носія цього права необхідно розглядати як біосоціальну істоту, яка володіє здатністю жити не лише як біологічний вид, але і як соціальний. Відпо- відно, людина включає поняття «особистість» та «індивід», де поняттю особистості відповідають соціальна і духовна сторони людського буття, а поняттю «індивід» - біологічна, природна сторона. Коли ми вживаємо поняття «індивід», значить йдеться про людину як частину природи. Натомість особистість - це як результат соціалізації індивіда. Особистість $€$ категорією духовною, а індивід - це категорія натуралістично-біологічна. Враховуючи це, характеристика людини має виходити з її біологічних ознак з акцентом на соціальну, культурну, духовно-моральну сторону. Людина - це біосоціальна істота, яка володіє такими тільки їй притаманними ознаками, як: свідомість, свобода, творчість, мислення, мова тощо і поєднує фізичний, соціальний, духовний та моральний аспекти. Тому об'єктом правової охорони права на життя $\epsilon$ життя як єдність буття у трьох його формах: фізіологічній, соціологічній та внутрішній (духовній).

\section{ЛITEPATУPA:}

1. Конституція України від 28 червня 1996 р. № 254к/96-ВР. Відомості Верховної Ради України. 1996. № 30. Ст. 141.

2. Зайцева А.М. Жизнь человека как объект конституционно-правового регулирования : дисс. ... канд. юрид. наук : 12.00 .02 ; Моск. гос. ун-т им. М.В. Ломоносова. Москва, 2009. 237 c.

3. Філософія права : підруч. для студ. юрид. вищ. навч. закл. / О.Г. Данильяк та ін. ; за ред. д-ра філос. наук, проф. О.Г. Данильяна. Харків : Право, 2009. 208 с.

4. Федорова А.Л. Право на життя як невід'ємне природне право людини. Актуальні проблеми міжнародних відносин. 2009. Випуск 83. Частина II. С. 43-49.

5. Мамут Л.С. Декларация прав человека и гражданина 1789 г. - веха на пути к универсальной концепции прав человека. Права человека в истории человечества и в современном мире. Москва : Институт государства и права АН СССР, 1989. С. 29-34.

6. Шкурная Е.В. Жизнь как объект права : дисс. ... канд. юрид. наук : 12.00 .01 ; Московский университет МВД РФ. Москва, 2010. 150 с.

7. Рассказов Л.П., Упоров И.В. Естественные права человека : учебное пособие. СанктПетербург : Лексикон, 2001. 96 с.

8. Середа О.О. Щодо питання природності природних прав людини: теоретичний аспект. Медичне право України: правовий статус пацієнтів в Україні та його законодавче забезпечення (генезис, розвиток, проблеми і перспективи вдосконалення). Львів, 2008. С. 284-288.

9. Кузьменко Я.П. Теоретико-правові засади права людини на життя : дис. ... канд. юрид. наук : 12.00.01; Держ. вищ. навч. заклад «Запорізький нац. ун-т». Запоріжжя, 2015. 196 с.

10. Капицын В.М. История, теория и защита прав человека : учебн. Москва : Москов. ун-т потребительской кооперации, 2003. 260 с.

11. Бабаджанов И.Х. Гражданско-правовые проблемы права на жизнь и здоровье : дисс. ... канд. юрид. наук : 12.00.03. Душанбе, 2004175 с.

12. Декларация независимости Соединенных Штатов Америки. 4 июля 1776 / Конституции и законодательные акты буржуазных государств XVII-XIX. Москва : Государственное издательство юридической литературы, 1957. URL: http://www.vostlit.info/Texts/Dokumenty/S. America/XVIII/1760-1780/Deklac_nezavisim/text.phtml?id=4684 
13. Бігун В.С. Людина в праві: аксіологічний підхід : автореф. дис. ... канд. юрид. наук : 12.00.12. Київ, 2004. 19 с.

14. Философский энциклопедический словарь / ред. кол. С.С. Аверинцев и др. Москва : Сов. энцикл., 1989. 814 с.

15. Шульга А.М. Загальнотеоретичні аспекти правомірної поведінки особи : монографія. Харків : Майдан, 2013. 412 с. С. 5-6.

16. Філософія права: проблеми та підходи : навч. посіб. / П.М. Рабінович та ін. ; за заг. ред. П.М. Рабіновича. Львів : Юрид. фак. Львівського національного університету імені Івана Франка, 2005. 332 с.

17. Круглова Л.К. Социализм. Человек. Культура : монография. Москва, Высш. шк., 1990. $144 \mathrm{C}$.

18. Колесов М.С. Человек и культура: Философскиеразмышления. Киев : Издательство общества «Знание» Украины, 1991. 48 с.

19. Матузов М.И. Личность. Права. Демократия. Теоретические проблемы субъективного права. Саратов : Изд. Саратов. Ун-та, 1972. 290 с.

20. Бермічева О.В. Індивідуальність людини і право на індивідуальність особистості. Вісник Академії адвокатури України. 2011. Число 3. С. 11-20. 